\title{
The Heyday of Teleology and Early Modern Philosophy
}

\section{Citation}

McDonough, Jeffrey K. 2011. "The Heyday of Teleology and Early Modern Philosophy." Midwest Studies In Philosophy 35, no. 1: 179-204.

\section{Published Version}

doi:10.1111/j.1475-4975.2011.00218.x

\section{Permanent link}

http://nrs.harvard.edu/urn-3:HUL.InstRepos:12714548

\section{Terms of Use}

This article was downloaded from Harvard University's DASH repository, and is made available under the terms and conditions applicable to Open Access Policy Articles, as set forth at http:// nrs.harvard.edu/urn-3:HUL.InstRepos:dash.current.terms-of-use\#OAP

\section{Share Your Story}

The Harvard community has made this article openly available.

Please share how this access benefits you. Submit a story.

Accessibility 
Published as: Jeffrey K. McDonough, "The Heyday of Teleology and Early Modern

Philosophy," in John Carriero, ed. Early Modern Philosopby Reconsidered, Midwest Studies in Philosophy (35) 2011: 179-204.

\section{The Heyday of Teleology and Early Modern Philosophy}

Jeffrey K. McDonough

\section{PENULTIMATE DRAFT}

\section{Introduction}

A standard accounting of the friends and foes of traditional teleology in the early modern period casts central figures of the era in familiar roles. Descartes's promise to banish final causes from his physics is presented as foreshadowing a general shift away from teleological explanations by proponents of the mechanical philosophy (Principles 1:28/CSM 1:202; see also, Meditations IV/CSM 2:39). Spinoza's denunciation of final causes as "nothing but human fictions," and his suggestion that teleological explanations threaten to "turn the order of nature completely upside down," is treated as heralding an even more radical critique of teleological modes of explanation (Ethics 1, Appendix/Geb 2:80). Finally, Leibniz's repeated assurances that the "Kingdom of Wisdom" and the "Kingdom of Power" are always and everywhere in perfect harmony is framed as a characteristic attempt to reconcile the explanatory approaches of the ancient and modern worlds (GM VI.242-243/AG 126; A.II.i.501/AG 242). All in all, on this familiar accounting one is left with a broad-brush picture of traditional teleology as assailed on one front by mainstream proponents of the New Science, on another front by enlightened freethinkers, and defended on both sides by the ever-conciliatory eclectic from Hannover. 
In an important recent paper, Don Garrett has argued for a radical reassessment of early modern attitudes towards traditional teleology. Focusing on the "early modern rationalists," Garrett proposes to consider "the answers given by Aristotle, Descartes, Leibniz and Spinoza to four basic questions about the nature and range of teleology and teleological explanation: Whether there is teleology not dependent on thought? Whether there is teleology through divine will or purpose? Whether there is subhuman teleology? Whether there is a substantive role for teleological explanations in natural philosophy? Having answered each of these four questions on behalf of the four philosophers he considers, Garrett concludes dramatically that (i) "although Spinoza maintains a certain rhetorical distance from the Aristotelian vocabulary of final causes, he fully and consistently accepts the legitimacy of many teleological explanations;" (ii) "in two of the most important respects, Leibniz's position on teleology is not more, and is perhaps even less, Aristotelian than Descartes's;" and (iii) "overall, among the three seventeenthcentury philosophers under discussion, it is not Leibniz but Spinoza who holds the position on teleology and teleological explanations nearest to Aristotle."

In what follows I wish to argue, contra Garrett, that the standard reckoning of early modern proponents and opponents of traditional teleology in fact tracks something deep and important in the period's shifting attitudes towards teleology and teleological explanations. Towards that end, the first section returns to the "heyday" of teleology in the ancient and early medieval eras in order to identify two central commitments of

\footnotetext{
${ }^{1}$ Don Garrett, "Teleology in Spinoza and Early Modern Rationalism," in New Essays on the Rationalists, ed. Rocco J. Gennaro and Charles Huenemann (Oxford: Oxford University Press, 1999), 311-12, 25-33.
} 
traditional teleology, namely, that teleological explanations are on a par (or better) with efficient causal explanations, and that the objective goodness of an outcome may explain its coming about. The second section argues that mainstream later medieval and early modern philosophers opposed the teleology of their predecessors not so much by restricting its scope, but rather by denying one commitment of the heyday of teleology, what I'll call "the thesis of explanatory parity." The third section argues that Spinoza's rejection of traditional teleology is similarly rooted not so much in a desire to drive out

all possible forms of teleological explanation but rather in his rejection of another central commitment of the heyday of teleology, what I'll call the "thesis of explanatory goodness." Finally, the fourth section argues that Leibniz's status as a champion of traditional teleology rests securely on his attempt to defend, in often novel and challenging ways, both the theses of explanatory parity and goodness. The essay concludes by briefly returning to Garrett's proposed reevaluation, and drawing three general lessons concerning the assessment of early modern attitudes towards traditional teleology.

\section{The Heyday of Teleology: Explanatory Parity and Goodness}

At a bare minimum, a teleological explanation purports to explain an event, process or state of affairs in terms of a likely or possible consequence of that event, process or state of affairs. So, for example, the suggestions that fire rises in order to reach its natural place in the heavens and that my daughter went into the kitchen in order to get a cookie 
are both at least candidates for teleological explanations. They purport to explain some process - an element's rising, someone's going into the kitchen - by appealing to a likely or possible consequence of that process - fire's finding its natural resting place, my daughter's getting a snack. Likewise, the suggestions that the North Star exists in order to guide ships at night, and that humans have eyes in order to see, are at least in the running to be teleological explanations. The first purports to explain the existence of a particular star by appealing to a consequence of its existence - namely that it can be used for purposes of navigation - while the second purports to explain our having eyes by appeal to the contribution they make to the larger whole of which they are a part. If it is granted that we have some handle on the notion of what a teleological explanation is, we can allow teleology itself to refer to any event, process or state of affairs that admits of a teleological explanation.

In turning to the views of ancient and early medieval philosophers, one is likely to be struck first by the sheer range of teleological explanations they commonly endorsed. Philosophers of the period generally allowed that both rational beings - including God, angels, and humans - as well as non-rational creatures - including animals, plants and even elements - could rightfully be construed as acting for the sake of ends. That is to say, they typically held that divine, finitely rational, and even natural actions could be explained by appeal to their likely or expected outcomes. Ancient and early medieval philosophers furthermore commonly assigned various teleological functions to creatures and their parts. It was commonly assumed, for example, that every creature has an end insofar as it contributes to the perfection of the universe as a whole, and every organ of a creature has as an end the flourishing of the creature of which it is a part. Thus, Aquinas, 
for example, insists that "even as that which acts by intelligence tends by its action to a definite end, so also does that which acts by nature ... [so that] every agent acts for an end," adding (elsewhere) that "capacities do not exist on account of organs, but organs on account of capacities ... [so that] different capacities do not exist on account of different organs; but instead, nature has established this difference in organs so as to match with the difference in capacities" (SCG III.2; ST I.78.3).

Although it is tempting to view this admittedly striking range of teleological explanations as the distinctive feature of the ancient and early medieval "heyday" of teleology, it is possible to see that range itself as rooted in a deeper, I think ultimately more revealing, core commitment. Medieval philosophers commonly held that goodness and being are in some sense identical, that, in Aquinas's way of putting the position, "Goodness and being are really the same, and differ only in idea," that is, they differ only in our way of conceiving them (ST I.5.1). On this view, existence and goodness are at a minimum necessarily coextensive: whatever actually exists is actually good, any potential existence is also a potential goodness, and - perhaps most shockingly to contemporary ears - any degree of goodness is also a degree of being. While no longer very popular today, this so-called doctrine of the "convertibility of the good" enjoyed a long and distinguished history that ran forward from Plato and Aristotle, wound its way through Boethius, Christian Neo-Platonism and the commentary tradition, and arguably culminated in high Scholastic Aristotelianism. ${ }^{2}$ It gave rise to two distinguishable, if historically intertwined, main lines of thought linking being and goodness.

\footnotetext{
${ }^{2}$ This history is lucidly sketched in Scott MacDonald's introduction to Scott MacDonald, ed., Being and Goodness: The Concept of the Good in Metaphysics and Philosophical
} 
The first main line of thought, naturally associated with Plato and the Platonist tradition, suggests that created being is metaphysically and causally dependent upon objective goodness. ${ }^{3}$ It drew support from the creation stories of both the Timeaus and the Old Testament. In the former, Plato offers as "the reason why the maker made becoming, and the universe" the fact that "He was good ... [and] Being devoid of envy, he wanted everything to be like himself, as far as possible." ${ }^{4}$ Likewise, the first book of Genesis emphasizes that after each day of creation "God saw that it was good," a theme on which Augustine sensibly comments:

God wasn't previously so ignorant that he could only discover that his work was good when it was complete. Far from it! Nothing he created would have been created if he hadn't known it very well beforehand. Therefore, when he sees that

Theology (Ithaca, NY: Cornell University Press, 1991) 1-28. My discussion of the theme of the convertibility of being and goodness is greatly indebted to this excellent collection of essays.

${ }^{3}$ For discussion of this theme, see especially Norman Kretzmann, "A General Problem of Creation: Why Would God Create Anything at All?," in Being and Goodness: The Concept of the Good in Metaphysics and Philosophical Theology, ed. Scott MacDonald (Ithaca, NY: Cornell University Press, 1991).

${ }^{4}$ Plato, “Plato Complete Works," ed. John M. Cooper and D.S Hutchinson (Indianapolis, IN: Hackett, 1997), Timaeus 29E-30B. For discussion of Plato's views on teleology, and further texts, see especially James G. Lennox, “Plato's Unnatural Teleology," in Platonic Investigations, ed. Dominic J. O'Meara, Studies in Philosophy and History of Philosophy (Washington, D.C.: Catholic University of America, 1985). 
a thing is good - a thing he wouldn't have made at all if he hadn't seen it was good before he made it - he is teaching us ... if we ask 'Who made it?, the answer is 'It was God'. If we ask 'How?', the answer is 'God said 'Let it be'; and it was'. If we ask 'Why?', the answer is 'Because it is good'.

The core idea expressed here by Plato and Augustine that creatures exist because they are objectively good was in turn closely associated with two further distinct, but intimately related thoughts. The first is that it belongs to the very nature of goodness to "diffuse" itself - that goodness, by its very essence, seeks to share, generate, and spread further goodness. This thought, commonly associated with the sixth century neo-Platonist "Dionysus" or "Psuedo-Dionysus," provided one line of response to the question of why a perfect being should bother creating at all: a good being, in virtue of the very nature of goodness, seeks of necessity to extend its goodness as far as possible. ${ }^{6}$ (Put conversely, a

${ }^{5}$ Augustine, "De Civitate Dei," in Patrologiae Cursus Completus, Series Latina, ed. J. P. Migne (Paris: 1844-64), xi.21. For discussion of Augustine's views on creation, and further texts, see especially Roland J. Teske, "The Motive for Creation According to Saint Augustine," The Modern Schoolman 65 (1988).

${ }^{6}$ On the history of this principle, see: Julien Peghaire, "L'axiome 'Bonum Est Diffusivum Sui' Dans Le Néoplatonisme Et Le Thomisme," Revue de l'Université d'Ottawa 1 (1932). Klaus Kremer, “Das 'Warum' Der Schoepfung: 'Quia Bonus' Vel/Et 'Quia Voluit'? Ein Beitrag Zum Verhaeltnis Von Neuplatonismus Und Christentum an Hand Des Prinzips 'Bonum Est Diffusivum Sui',, in Parusia: Studien Zur Philosophie Platons Und Zur Problemgeschichte Des Platonismus, Festgabe Fuer Johannes Hirschberger, ed. Kurt 
being that didn't wish to share its goodness couldn't, by dint of that very fact, be absolutely good.) On this view, the notion of a perfectly good being that does not create that does not share its goodness - is ultimately incoherent, a conceptual impossibility. The second idea is that every created being, to the extent that it exists, is good. This thought is especially prominent, of course, in Augustine's anti-Manicheanism. ${ }^{7}$ In place of the Manicheans' two coexisting and opposed forces of good and evil, Augustine suggests there is only goodness and its absence, only being and lack of being. Every creature is thus good, for Augustine, to the extent that it exists, and its moral or natural imperfections must be understood not as positive entities but rather as privations of appropriate forms and perfections.

The second main line of thought, naturally associated with Aristotle and the Aristotelian tradition, suggests that the ideas of being and goodness are linked in the notion of an end. ${ }^{8}$ Aristotelians typically held that every created substance is endowed with a substantial form that fixes both the general features in virtue of which it belongs to a particular genus and the more specific features in virtue of which it belongs to a

Flasch (Frankfurt am Main: Minerva, 1965). Kretzmann, "A General Problem of Creation: Why Would God Create Anything at All?," 217-20.

${ }^{7}$ See, for example, Augustine, “Confessiones," in Patrologiae Cursus Completus, Series Latina, ed. J. P. Migne (Paris: 1844-64), vii.3, 5.

${ }^{8}$ For discussion of this theme, see Eleonore Stump and Norman Kretzmann, "Being and Goodness," in Being and Goodness: The Concept of the Good in Metaphysics and Philosophical Theology, ed. Scott MacDonald (Ithaca, NY: Cornell University Press, 1991). 
particular species within its genus. Those latter features - the substance's "differentia"serve as the metaphysical grounds for the specific capacities a substance enjoys as a member of its species. For Aristotelians, a substance is more fully actualized to the extent that it realizes those specific capacities - oak trees and humans, for example, were held to become literally more fully oaks and humans as they matured, developed, and generally realized the characteristic capacities in virtue of which they could be counted as oaks and humans in the first place. In keeping with Aristotle's dictum that "goodness is what all desire," however, Aristotelians further held that those states towards which creatures tend in virtue of their substantial forms may also be identified with the specific goods of those creatures (see, SCG 3a.3, 3a.38). ${ }^{9}$ In growing into a mighty oak, a sapling thus not only realizes its characteristic capacities but also realizes it own natural goodness. For Aristotelians, the ends towards which creatures tend may thus be viewed equally well from the vantage of either being or goodness.

Although there are arguably important tensions between the Platonic and Aristotelian strategies for drawing connections between being and goodness, their common commitment to the convertibility of the good encouraged a pair of widely accepted commitments that will figure centrally in what follows.

First, both strategies agree that objective goodness is explanatory, that is to say, both agree that an object's or state of affair's objective goodness may figure importantly in explanations of that object's or state of affair's existence or tendency to exist. Thus, in

\footnotetext{
${ }^{9}$ See for example, Aristotle, "Nicomachean Ethics," in The Complete Works of Aristotle, ed. Jonathan Barnes (Princeton, New Jersey: Princeton University Press, 1984), book I, section 1.
} 
the Platonic account of creation, the objective goodness of the world and its creatures is invoked in an essential way in order to explain why God creates at all. Similarly, in the Aristotelian account of created substances, the natural development of creatures is explained by appeal to their intrinsic appetites for realizing their own specific, objective goods. Indeed, it is this commitment, Aquinas insists, that allows us to evaluate monsters and the like as having objective defects, rather than as mere irregularities (SCG IIIa.2). A bird born without wings, for example, could be seen on this view not merely as an aberration, but more strongly as a creature lacking an important perfection due to it. For ease of exposition, let's call this commitment the thesis of explanatory goodness.

Second, early to middle medieval philosophers generally agreed that teleological explanations are at least as explanatory as efficient causal explanations. Neo-platonic emmanantionist accounts of creation typically treat God as equally the first efficient and the first final cause of the created world. He is the first efficient cause in virtue of literally being the source of the world's being. He is the first final cause in virtue of being the highest good towards which all things are directed, and which all things, in their own way, seek to emulate. Aristotelians similarly did not see final and efficient causal explanations as being in anyway in tension with one another. They thus maintained that a full explanation of an event would cite, in addition to its material and formal causes, both its efficient and final causes. Indeed, Aristotelian scholastics characteristically insisted that the final cause is "the cause of causes, in as much as it is the cause of the causality of all the causes," suggesting that, if anything, final causes are 
even more basic, even more explanatory than efficient causes. ${ }^{10}$ Again, for ease of exposition, let's call the view that teleological explanations are on an explanatory par (or better) with efficient causal explanations the thesis of explanatory parity.

The theses of explanatory goodness and parity do not, of course, exhaust what is interesting and important about ancient and early medieval views on teleology. Indeed, part of what makes those early views so intriguing today is precisely the various ways in which they seek to bring together a widely shared commitment to teleology with their own distinctive metaphysical and epistemological outlooks. Nor do the theses of explanatory goodness and parity exhaust the teleological themes of interest to later medieval and early modern philosophers. A specific philosopher, at a specific time, might be every bit as much, or even more, concerned, for example, with issues such as the metaphysical basis of final causes, the practical application of teleology in the natural

${ }^{10}$ Thomas Aquinas, Opera Omnia: Ad Fidem Optimarum Editionum Accurate Recognita, 25 vols. (Parma: P. Fiaccadorie, 1852-73) xvi, 340. English translation available in Thomas Aquinas, St. Thomas Aquinas: Selected Writings, trans. Robert P. Goodwin (Indianapolis, IN: Bobbs-Merrill, 1965) 19. I set aside here the complex issue of whether Aristotelians are in general, or in specific instances, committed to there being a necessary connection between efficient causation and final causation, and, if so, to what sort of final causation. For discussion of this intriguing question, see especially: John Carriero, “Spinoza on Final Causality," Oxford Studies in Early Modern Philosophy 2 (2005): 11014. Paul Hoffman, "Does Efficient Causation Presuppose Final Causation? Aquinas Vs. Early Modern Mechanism," in Metaphysics and the Good, ed. Samuel Newlands and Larry M. Jorgensen (New York: Oxford University Press, 2009). 
sciences, the goal-directed capacities of non-rational animals, or the possibility of ecstatic union with God as a principal aim for humans beings. Nonetheless, as the next three sections will attempt to show, attention to the theses of explanatory goodness and parity may help to shed light on some important large-scale developments concerning teleology in the later medieval and early modern eras.

\section{Trouble in Paradise: Giving up Explanatory Parity}

In spite of long being cast as arch-opponents of traditional teleology, most mainstream early modern philosophers, including most early modern mechanists, continued to embrace a strikingly wide range of teleological explanations. It was commonly assumed for example that intelligent agents, including God, angels and humans could act for the sake of ends they cognize and intend. Furthermore, philosophers of the era generally supposed that the world itself was providentially designed by an omniscient and benevolent creator, and thus it was generally taken for granted that the parts of the world as well as the various organs of creatures were ordered to specific, often manifest, ends. Judged solely on the basis of the range of teleological explanations accepted at the time, mainstream early modern mechanists might be reckoned to be every bit as committed to teleology as their ancient and early medieval predecessors. ${ }^{11}$

\footnotetext{
${ }^{11}$ See, F. F. Centore, "Mechanism, Teleology, and Seventeenth Century English Science," International Philosophical Quarterly 12 (1972). Margaret J. Osler, “From Immanent Natures to Nature as Artifice: The Reinterpretation of Final Causes in Seventeenth-Century Natural Philosophy," The Monist 79, no. 3 (1996). Richard S.
} 
Nonetheless, an important shift away from traditional teleology did take place even among mainstream later medieval and early modern philosophers. The first step in that shift - highlighted long ago by Analise Meyer - involved an increasingly settled opposition to Aristotle's assimilation of the teleology of non-intelligent agents to the intrinsic teleology of intelligent agents. ${ }^{12}$ Thus, for example, Ockham emphasizes a distinction between final causes "intended by nature" and final causes "intended by the will." He argues that in either case a final cause can be efficacious only insofar as it is loved or desired by an intelligent agent that acts for its sake. ${ }^{13}$ As a result, he is led to a two-tiered picture of teleology that is, if anything, only too intuitive today. Intelligent agents, for Ockham, act for the sake of ends that they cognize and love. Those ends are

Westfall, Science and Religion in Seventeenth-Century Englad (Ann Arbor, MI:

University of Michigan Press, 1973).

${ }^{12}$ Anneliese Maier, "Das Problem Der Finalkausalität Um 1320," in Metaphysische Hintergründe Der Spätscholastischen Naturphilosophie, Her. Studien Zur Naturphilosophie Der Spätscholastik (Rome: Edizioni di storia e letteratura, 1955).

${ }^{13}$ William of Ockham, “Opera Philosophica Et Theologica,” ed. Gedeon Gál (St. Bonaventure, NY: The Franciscan Institute, 1967-88), Questiones Varia, Question 4, Volume VIII, 107-09, 13-14. For discussion, and further references to Ockham's views on teleology, see, especially, Marilyn M. Adams, “Ockham on Final Causality: Muddying the Waters," Franciscan Studies 56 (1998). See, also: Stephen F. Brown, "Ockham and Final Causality," in Studies in Medieval Philosophy (Washington, D. C. : The Catholic University of America Press, 1987). Gerhard Leibold, "Zum Problem Der Finalität Bei Wilhem Von Ockham,” Philosophisches Jahrbuch 89 (1982). 
explanatorily relevant because they are intended by cognizing agents enjoying causally efficacious wills. Non-intelligent agents, on the other hand, act for the sake of ends only insofar as they have ends conferred upon them by "external" intelligent agents. ${ }^{14}$ They are consequently teleological only in the sense that tools and artifacts in general are teleological, enjoying ends derivatively in virtue of being designed and put to use by intelligent agents who alone act for the sake of ends in a full-blooded, non-derivative manner. $^{15}$

Such a two-tiered picture of teleology, of course, fit well with the view of nature commonly favored by mainstream early modern mechanists. Thus, to consider one prominent example, Robert Boyle, in his appropriately entitled Disquisition About the Final Causes of Natural Things: Wherein it is inquired, Whether, and (if at all) with what Cautions, a Naturalist should admit them, suggests that a natural agent may act for the sake of an end when it "is indeed so directed, as it ought be to obtain an end, and yet that end is neither known nor intended by the proximate agent, but by a remoter agent, that is intelligent." ${ }^{16}$ Understood in this way, Boyle could fathom no reason for denying natural

${ }^{14}$ Ockham, “Opera Philosophica Et Theologica," Sent. Prologue, Question 11, Volume I, 308. Ockham p. 308; cited in Adams 1998, 10-11

${ }^{15}$ For a later example from the Scholastic tradition, see Francisco Suárez, Disputationes Metaphysicae, 2 vols. (Hildesheim: G. Olms, 1965) xxiii.10.5-6.

${ }^{16}$ Robert Boyle, "A Disquisition About the Final Causes of Natural Things," in The Works of the Honourable Robert Boyle, ed. Thomas Birch (Hildesheim: Georg Olms, 1966), 413. For discussion of Boyle's views on teleology, see: Laurence Carlin, “The Importance of Teleology to Boyle's Natural Philosophy," British Journal for the History 
teleology in general, since, as he believed, surely God could arrange bits of matter in such a way that "each part of this great engine, the world, should, without either intention or knowledge, as regularly and constantly act towards the attainment of the respective ends which He designed them for, as if they themselves really understood, and industriously prosecuted, those ends." ${ }^{\prime 17}$ Nor could Boyle see any reason to follow Descartes's proposal to disregard final causes in the pursuit of physics on what seemed to him to be the overly cautious grounds that it would be rash to consider oneself "capable of investigating the purposes of God" (AT 7:55/CSM 2:39). While acknowledging that piety demands that we not hope to know all of God's intentions in creating the world, Boyle contends that we might nonetheless hope, with all due modesty, to know some of his ends. Indeed, he goes a step further, suggesting that it might even be viewed as a duty to "believe that some of the ends, to which He destined divers of his corporeal works, were to exert and communicate his exuberant goodness, and to receive from his intelligent creatures, such as men, an ardent love, a high admiration, and an obsequious gratitude, for having displayed so much wisdom and beneficence....". ${ }^{18}$ Given their view

of Philosophy 19, no. 4 (2011). James G. Lennox, "Robert Boyle's Defense of Teleological Inference in Experimental Science," Isis 74 (1983). Osler, "From Immanent Natures to Nature as Artifice: The Reinterpretation of Final Causes in SeventeenthCentury Natural Philosophy.” Timothy Shanahan, “Teleological Reasoning in Boyle's Disquisition About Final Causes," in Robert Boyle Reconsidered, ed. Michael Hunter (Cambridge: Cambridge University Press, 1994).

${ }^{17}$ Boyle, "A Disquisition About the Final Causes of Natural Things," 413.

${ }^{18}$ Ibid., 98 
of God as the supreme craftsman of the world-machine, it should be no surprise that pious proponents of the mechanical philosophy typically assumed that parts of the world are ordered to ends, and that some of those ends might be readily discerned even by our admittedly weak but inquisitive minds.

Viewed from the perspective of the theses of explanatory goodness and parity, the outlook of mainstream mechanists with respect to the teleology of non-intelligent agents may be seen as a partial break with the ancient and early medieval tradition. On the one hand, mechanists continued to maintain the thesis of explanatory goodness with respect to non-intelligent agents. That is to say, they continued to insist that, for example, rocks fall and air rises because of the goodness God sees in those results; that birds have wings and fish have gills because God wants them to realize states of affairs that he recognizes to be good. On the other hand, in affirming that non-intelligent agents may enjoy intrinsic efficient causal powers, while denying that they may enjoy intrinsic ends, mechanists effectively abandoned the thesis of explanatory parity with respect to nonintelligent agents. Indeed, that asymmetry with respect to non-intelligent agents is of the essence of the two-tier picture of teleology of the mechanistic outlook: rocks and fire, wings and gills may all be counted as efficient causes in virtue of their intrinsic natures, but may have ends ascribed to them only in virtue of their extrinsic relations to intelligent beings. As Margaret Osler has nicely put it, mainstream mechanical philosophy didn't simply do away with natural teleology, but rather "reinterpreted" it, so that "in the place of natures containing their own immanent finality, Nature as a whole came to be viewed 
as the creation of a divine artificer, whose wisdom is reflected in the design of the creation., $^{\text {19 }}$

The second step in the shift away from traditional teleology among mainstream early modern philosophers concerns more directly the teleology of intelligent agents. Although the doctrine of the convertibility of the good encouraged acceptance of both the thesis of explanatory parity and the thesis of explanatory goodness, taken together they were never easily reconciled with traditional religious views concerning freedom and responsibility. For both theses taken together suggested to many a kind of moral determinism in the case of finite rational agents and a kind of moral necessitarianism in the case of God that many believers found anathema. If my actions, for example, can be explained in terms of the goodness I expect to result from them, and teleological explanations are on a par with efficient causal explanations, then my choosing between two possible outcomes may appear to be as determined by their perceived goodness as the movements of a scale are by the weights placed in its pans. Similarly, the theses of explanatory parity and goodness, viewed against the background of widespread assumptions about God's necessary nature and omniscience, suggest that God is necessarily determined to choose whatever is in fact the best; that, as we might put it, there is no possible world in which God fails to act in an absolutely perfect manner - a consequence nicely anticipated in Plato's remark that "For him who is most good, it

${ }^{19}$ Osler, "From Immanent Natures to Nature as Artifice: The Reinterpretation of Final Causes in Seventeenth-Century Natural Philosophy," 403. But, see also, Laurence Carlin, "Boyle's Teleological Mechanism and the Myth of Immanent Teleology,” Studies in the History and Philosophy of Science (forthcoming). 
neither was nor is permissible to do anything other than what is most beautiful," and a result not incidentally denounced in Bishop Stephen Tempier's influential condemnation of $1277 . .^{20}$

Many philosophers in the later medieval and early modern eras responded to this apparent tension by placing new emphasis on the will's being an efficient power for selecting among alternatives in a way that is not fixed by the actual or perceived goodness of those alternatives. Thus Scotus, for example, , famously argues that the rational will should be understood as a "self-determining power for opposites" endowed with a "superabundant sufficiency" in virtue of which it is able to transcend any inclinations or tendencies that it might possess. ${ }^{21}$ This implies, according to Scotus, that we, as finite rational agents, are free to will or not will any good, nil or not nil any evil,

${ }^{20}$ Plato, "Plato Complete Works," Timaeus 30B. For a helpful overview of the condemnation of 1277, see Hans Thijssen, "Condemnation of 1277," in The Stanford Encyclopedia of Philosophy, ed. Edward N. Zalta (Fall 2008).

${ }^{21}$ See, for example, Ordinatio III, d. 17, Ordinatio IV, d.29 in Allan B. Wolter, ed., Duns Scotus on the Will and Morality (Washington, D. C.: The Catholic University of America Press, 1986) 182, 76. For discussion of Scotus's view of the will, see: Marilyn M. Adams, "Duns Scotus on the Will as Rational Power," in Via Scoti: Methodologica Ad Mentem Joannis Duns Scoti, ed. Leonardo Sileo (Roma: 1995). John Boler, "Transcending the Natural: Duns Scotus on the Two Affections of the Will," The American Catholic Philosophical Quarterly 67 (1993), ibid. Allan B. Wolter, "Duns Scotus on the Will as a Rational Potency," in The Philosophical Theology of John Duns Scotus, ed. Marilyn M. Adams (Ithaca: Cornell University Press, 1990). 
and indeed even to knowingly choose a lesser good over a greater good or a greater evil over a lesser evil. Similarly, Scotus insists that the divine will is not inclined "determinately to anything but its own goodness. ... For to any other object it is related only contingently, in such a way that it can [tend] equally to that object and to its opposite." 22 Similar views concerning the will became prevalent among prominent early modern mechanists including, for example, Gassendi, Boyle and Newton. ${ }^{23}$ Indeed, even Descartes, sometimes interpreted as a compatabilist on largely philosophical grounds, generally seems to favor a liberty of indifference, writing, for example, that the will has "a positive faculty of determining [itself] to one or other of two contraries" and insisting that it "is self-contradictory to suppose that the will of God was not indifferent from

${ }^{22}$ John Duns Scotus, "Works," ed. Luke Waddington (Hildesheim: Georg Olms, 1639), Ordinatio 4, d. 46. track down passage (cited Williams 1998, p. 172). The extent to which Scotus's God can act in a fully arbitrary manner - as opposed to being constrained by his own perfect nature - has recently become a topic of important debate. For further discussion and texts, as well as entry into the debate, see: Richard Cross, "Duns Scotus on Goodness, Justice, and What God Can Do," Journal of Theological Studies 48, no. 1 (1997). Thomas Williams, “The Unmitigated Scotus,” Archiv für die Geschichte der Philosophie 80 (1998). Wolter, ed., Duns Scotus on the Will and Morality. 23 For texts and discussion see respectively: Lisa T. Sarasohn, Gassendi's Ethics: Freedom in a Mechanistic Universe (Ithaca, NY: Cornell University Press, 1996) 76-97. Jan W. Wojcik, Robert Boyle and the Limits of Reason (Cambridge: Cambridge University Press, 2002) 189-211. B. J. T. Dobbs, The Janus Faces of Genius: The Role of Alchemy in Newton's Thought (Cambridge: Cambridge University Press, 1991) 110-17. 
eternity with respect to everything which has happened or will ever happen" (CSM 3:245/AT 4:173; CSM 2:291/AT 7:431-432). ${ }^{24}$

No one should suppose that in embracing a liberty of indifference later medieval and early modern philosophers thereby rejected intelligent teleology altogether. To say that a free agent has it within her power to accept or reject any end is certainly not to deny that she acts for the sake of ends. The fact that it is always within my power to either eat or not eat the candy bar in front of me in no way suggests that my eating the candy bar is not a goal-directed activity. Nor, for that matter, does a commitment to libertarianism rule out the possibility that goodness may figure centrally in explanations of the actions of intentional agents. Even if it is within an agent's power, for example, not to help her neighbor, she might nonetheless help her neighbor because she thinks it is the right thing to do, and her thinking that it is the right thing to do might well help to explain why she in fact came to the aid of her neighbor. Likewise, even voluntarism and every confirmed libertarian in the era appears to have been a suspected voluntarist is consistent with a commitment to both the teleology of intelligent agents and the thesis

${ }^{24}$ It should be acknowledged that Descartes's stance with respect to the doctrine of the liberty of indifference is especially difficult to make out. For an interpretation friendly to the present point, see especially Dan Kaufman, "Infimus Gradus Libertatis? Descaretes on Indifference and Divine Freedom," Religious Studies 39 (2003). For a more general discussion, and framing of the issue, see Robert JR. Sleigh, Vere Chappell, and Michael Della Rocca, "Determinism and Human Freedom," in The Cambridge History of Seventeenth-Century Philosophy, ed. Daniel Garber and Michael Ayers (Cambridge: Cambridge University Press, 2003). 
of explanatory goodness. For even voluntarists can allow that finite rational agents act for the sake of goods voluntarily decreed by God, and that God himself may act through a consequent will for the sake of goods determined by his antecedent will. ${ }^{25}$

Nonetheless, a libertarian view of the will does imply that final and efficient causes cannot be on an explanatory par at least as far as the volitions of intelligent agents are concerned. For while final causes may give an agent reasons for acting in one way rather than another, they can never - by design - fully explain her volitions. On the libertarian view, a free will is, and must be, first and foremost a self-determining efficient cause, and explanations of the actions of rational agents must ultimately terminate not in ends or reasons but in explanatorily basic and unanalyzable efficient volitions. In explaining why I ordered the chocolate ice cream, one may note that it is my favorite flavor, that I have always chosen chocolate in the past, and that my only other option was pistachio, which I detest. But while all these considerations may be relevant to the choice I make, they cannot, if the libertarian is right, fully explain my choice. For given all the conditions of my choice I could still, through an efficient act of the will, have chosen otherwise. The rise of libertarian conceptions of the will in the later medieval and early modern eras thus allowed philosophers and theologians to distance themselves from the thesis of explanatory parity even as they upheld the thesis of explanatory goodness.

Where does all this leave us? If we pause to take stock at this point in our narrative, two conclusions seem warranted. First, it would be a mistake to suppose that teleology and teleological explanations simply disappeared with the rise of the mechanical philosophy in the early modern period. On the contrary, as we've seen,

\footnotetext{
${ }^{25}$ See Tad Smaltz, "Descartes's Critique of Scholastic Teleology,” (2011), section 2.
} 
teleological explanations were still widely employed both with respect to intelligent and even - albeit derivatively - to non-intelligent agents. Second, an important shift nonetheless did take place in mainstream attitudes towards teleology in the later medieval and early modern eras. Spurred largely by theological considerations, philosophers of the period began to distance themselves from the once attractive view that an action or state of affairs might be explained equally well, or even better, in terms of the goodness it might bring about as well as in terms of the efficient causes that produce it. While teleology wasn't simply thrown overboard by mainstream later medieval and early modern philosophers, its explanatory role relative to efficient causal explanations was demoted in an important and significant way. As we will see in the next section, Spinoza, working well outside the mainstream, responded to the developments of his time with an equally dramatic, but almost oppositely oriented assessment of the teleological views of his ancient and early medieval predecessors.

\section{Trouble in Paradise: Giving up Explanatory Goodness}

Although Spinoza is often cast as the archenemy of teleology in the early modern period, there is, as Don Garrett has recently noted in detail, a rather strong textual case for supposing that he never meant to deny that humans, at least, regularly act for the sake of ends. ${ }^{26}$ Thus, for example, in the Treatise on the Emendation of the Intellect, Spinoza

\footnotetext{
${ }^{26}$ Garrett, "Teleology in Spinoza and Early Modern Rationalism,” 312-14. For interpretations of Spinoza that see him as being deeply hostile to teleology see: Jonathan Bennett, "Spinoza and Teleology: A Reply to Curley" (paper presented at the Spinoza:
} 
offers to explain much of human activity in terms of the ends of procuring "wealth, honor, and sensual pleasure" while accounting for his own philosophical activity in terms of being aimed at "the end" of obtaining a nature that will be "much stronger and more enduring" than the one he has presently (sections 1-14/Geb 2:5-9). Likewise, in Parts III, IV, and V of the Ethics, Spinoza makes repeated use of the notion that humans seek out various goals, maintaining, for example, that "We strive to further the occurrence of whatever we imagine will lead to Joy, and to avert or destroy what we imagine is contrary to it, or will lead to sadness" and that "When we love a thing like ourselves, we strive, as far as we can, to bring it about that it loves us in return" (Ethics 3p28/Geb 2:161; Ethics 3p33/Geb 2: 165). Finally, even in the Appendix to Part I of the Ethics, in the thick of his famous rejection of divine teleology, Spinoza offers human activity as a contrast to divine activity; indeed he offers it as the very root of our false attribution of

Issues and Directions, Leiden, 1990), Jonathan Bennett, A Study of Spinoza's Ethics (Indianapolis: Hackett Publishing, 1984). Carriero, "Spinoza on Final Causality.” For interpretations that see room for teleology, and especially human teleology, in Spinoza's system, see: Edwin Curley, "On Bennett's Spinoza: The Issue of Teleology” (paper presented at the Spinoza: Issues and Directions, Leiden, 1990). Michael Della Rocca, "Spinoza's Metaphysical Psychology," in The Cambridge Companion to Spinoza, ed. Don Garrett (New York: Cambridge University Press, 1993). Martin Lin, "Teleology and Human Action in Spinoza," Philosophical Review 115, no. 3 (2006). Richard Manning, "Spinoza, Thoughtful Teleology, and the Causal Significance of Content," in Spinoza: Metaphysical Themes, ed. Olli Koistinen and John Biro (New York: Oxford University Press, 2002). 
ends to God. Thus after declaring that "men commonly suppose that all natural things act, as men do, on account of an end," he goes on to explain that since "men always act on account of an end ... they seek to know only the final causes of what has been done" so that when they find many natural things beneficial to themselves they "infer that there was a ruler, or number of rulers of nature, endowed with human freedom, who had taken care of all things for them, and made all things for their use" (Geb 2:78). These texts lend, at the least, prima facie support to the view that Spinoza never meant to deny what is, in fact, very hard to deny, namely, that human beings regularly act for the sake of ends - that, for example, they sometimes relocate in order to avoid persecution, work in order to earn a living, and write books in order to influence opinion.

If it is granted, however, that Spinoza is committed to the view that human beings regularly act for the sake of ends, then it should further be granted that he is also committed to other finite modes acting for the sake of ends as well. A short path to this conclusion is provided by Spinoza's naturalism, which, as Michael Della Rocca has nicely emphasized, leads him to deny the presumption that human beings represent a distinguished subclass of entities to which special laws and forms of explanation might be uniquely applicable - to deny, that is, that human beings are "in nature as a dominion within a dominion" (Geb 2:137). ${ }^{27}$ A teleological understanding of Spinoza's account of human activity thus implies a teleological reading of Spinoza's highly controversial conatus doctrine as well, according to which: Each thing, as far as it can by its own power, strives to persevere in its being (Unaquaeque res, quantum in se est, in suo esse persevarare conatur) (Ethics 3p6). Considered in isolation, this brief statement

${ }^{27}$ Michael Della Rocca, Spinoza (New York: Routledge, 2008) 1-12. 
notoriously admits of both teleological and non-teleological readings. As Edwin Curley has noted, the terms "conatur" and "conatus" may be translated as "strives" and "striving," but may also be translated simply as "tends" and "tendency." 28 On the latter reading, Spinoza's conatus doctrine might well seem tantamount to a rejection of all finite teleology since it might be understood as implying that all singular things simply tend - without end or goal - to persevere in their being (much as one might suppose that all heavy things tend to fall when dropped without supposing that they have anything like the center of the earth as their goal). A teleological understanding of Spinoza's account of human activity, however, when paired with his naturalism suggests just the opposite conclusion. That is, it suggests that with his conatus doctrine, Spinoza means to assert that all singular things strive, as humans strive, for the sake of ends, and in particular for the sake of preserving their own being. To suppose otherwise would be to carve out a special domain of human activity of just the sort that Spinoza's naturalism resolutely rejects.

Against this line of thought, it might be suggested that a teleological understanding of Spinoza's conatus doctrine would imply, in light of his naturalism, that God, or nature as a whole, must also be counted as a teleological agent - a conclusion Spinoza clearly means to reject (see especially, Ethics 1: appendix/Geb 2:77-96). Spinoza, however, could reasonably hope to resist this imagined slide from mundane to divine teleology. For the teleology that the conatus doctrine attributes to finite singular things is rooted in their supposed striving to preserve their being - in the suggestion that

\footnotetext{
${ }^{28}$ Curley, "On Bennett's Spinoza: The Issue of Teleology", 48. See also, Garrett, "Teleology in Spinoza and Early Modern Rationalism," 313.
} 
creatures act in order to maintain their existence in the face of forces arrayed against them. But Spinoza might reasonably deny that teleology so understood is similarly applicable to God or nature taken as a whole. For while we can make sense of the notion of a finite singular thing striving to persevere in a sea of rival singular things, it is not at all clear that we can make sense of an absolutely necessary being - against whom no forces are or could possibly be arrayed - as "striving to preserve in its being." The point is not that the very notion of a necessary, yet teleological being is incoherent - it's not. ${ }^{29}$ But rather that Spinoza's own reasons for allowing that finite beings act for the sake of ends do not force him to also allow that God or nature as a whole must act for the sake of ends.

It might still be objected that conatus's role in seventeenth century mechanics nonetheless requires a non-teleological reading of Spinoza's conatus doctrine. For it might be supposed that the concept of conatus as found in seventeenth century mechanics is essentially non-teleological, and that if Spinoza's naturalism requires there to be only a difference in degree between the bodies studied by physicists and the beings studied by psychologists, then the concept of conatus found in Spinoza's psychology must also be essentially non-teleological. Although this challenge raises a host of interesting and

${ }^{29}$ Early in his career, Leibniz, for example, suggests that the laws of nature might hold of necessity and yet nevertheless be providentially designed insofar as they follow from God's intellect and will (A VI.ii.160; A VI.iii.364). See, also Leibniz's comments on a letter sent from Spinoza to Oldenburg (who later shared it with Leibniz), A.VI.iii.364, especially note 1. Cf. Garrett, "Teleology in Spinoza and Early Modern Rationalism," $328-29$. 
difficult issues running deep into Spinoza's philosophy, it might suffice for our present purposes to simply note, as a first round response, that the concept of conatus as used by seventeenth century mechanists was, in fact, by no means essentially non-teleological. The widespread impression to the contrary is most likely due to Newton's first law of motion, which admittedly suggests not only an intuitive account of something's moving as far as it can by its own power (quantum in se est), but also of something's having a tendency without its having a tendency for the sake of anything - of, say, an asteroid's moving by itself with a certain velocity, but with no natural goal or end. As I. B. Cohen has shown in detail, however, the focal meaning of the crucial phrase "quantum in se est," common to the writings of Descartes, Spinoza, Newton, and many others, concerns not the question of efficient vs. final causation at all, but rather the question of whether bodies move of their own nature or only as the result of an ongoing application of external forces. ${ }^{30}$ Spinoza's commitment to traditional seventeenth century mechanism to the extent that he was committed to it - is not therefore sufficient to rule out a

${ }^{30}$ It is for this reason that Newton was able suppose that his first law of motion had been anticipated even by Aristotle - not because Newton thought that Aristotle was an opponent of teleology, but because he thought, on the basis of passages from the Physics and Meteors, that Aristotle had believed that bodies would continue to move under idealized conditions even absent the application of external forces. See, I. Bernard Cohen, “'Quantum in Se Est': Newton's Concept of Inertia in Relation to Descartes and Lucretius," Notes and Records of the Royal Society of London 19 (1964): 148. See also Tad Schmaltz, Descartes on Causation (New York: Oxford University Press, 2008) 87128. 
teleological reading of his conatus doctrine. For such a commitment would still leave open the central question of whether the conatuses enjoyed by simple bodies are to be understood on analogy to the conatuses enjoyed by beings like ourselves, as the texts cited above suggest, or the other way around, as many interpreters have imagined.

Having argued thus far that Spinoza need not be read as seeking to eliminate teleology altogether from his metaphysics, the most important point of the present section is that he should nonetheless be seen as departing significantly from the teleological tradition of his ancient and early medieval predecessors. The deepest roots of his opposition to traditional teleology can be found in his - at the time - revolutionary views concerning the nature of goodness itself. In the Preface to Part IV of the Ethics, Spinoza explicitly rejects the once standard view that species may be arranged in an objective hierarchy of being, with each species in turn serving as an objective standard for members of that species, insisting instead that "Perfection and imperfection ... are only modes of thinking, i.e., notions we are accustomed to feign because we compare individuals of the same species or genus to one another." Pushing the thought further, he continues:

As far as good and evil are concerned, they also indicate nothing positive in things, considered in themselves, nor are they anything other than modes of thinking, or notions we form because we compare things to one another. For one and the same thing can, at the same time, be good, and bad, and also indifferent. For example, Music is good for one who is Melancholy, bad for one who is mourning, and neither good nor bad to one who is deaf." (Ethics IV, preface; see also, Ethics IV, d1; Ethics IV, d2). 
By Spinoza's lights, the traditional belief in objective goodness is simply a myth arising from our tendency to "form universal ideas of natural things," to treat those ideas "as models of things," and to imagine that when something happens in nature which does not agree with those models "Nature itself has failed or sinned, and left the thing imperfect" (Ethics IV, preface). As a consequence he is committed to denying that, for example, God creates the world because it is good, that I help my neighbor because it is the right thing to do, and that birds have wings because wings are a perfection of their essential nature.

Because he rejects objective goodness altogether, Spinoza must also reject the traditional view that things may be explained by appeal to their objective goodness, a commitment that comes out perhaps most clearly in his important treatment of human agency in Part III of the Ethics. There he suggests that to suppose that human beings strive for what they think is good is to get the relationship between goodness and human ends exactly the wrong way around. Having argued that appetite "is nothing but the very essence of man, from whose nature there necessarily follow those things that promote his preservation," (P9, dem) Spinoza declares:

From all this, it is clear that we neither strive for, nor will, neither want (appetere), nor desire anything because we judge it to be good; on the contrary, we judge something to be good because we strive for it, will it, want it (appetimus), and desire it. (Ethics III, p9s)

On Spinoza's view, our natures dictate that we have certain self-preserving appetites. Those appetites in turn lead us to pursue specific ends and avoid others. We then judge things to be good or bad as they agree or disagree with the ends we pursue. According to 
Spinoza, the miser desires wealth and therefore "judges an abundance of money best, and poverty worst." The ambitious person "desires nothing so much as Esteem and dreads nothing so much as Shame" and so views the former as good and the latter as bad. The envious person finds nothing more "agreeable than another's unhappiness, and nothing more burdensome than another's happiness" and so sees the very welfare that others seek as bad, and the miseries they aim to avoid as good (Ethics III, p39s). Thus by Spinoza's lights, traditional accounts of human agency according to which we seek what we view to be good and shun what we view to be bad confuse explanans and explanadum. $\mathrm{He}$ proposes instead that our actions towards ends are not to be explained in terms of what we perceive as good and bad, but rather that our perceiving things as good or bad is to be explained by the fact that our actions are directed towards those things.

Essentially the same line of thought, I believe, lies behind one of the most controversial passages in all of the Ethics. In the famous Appendix to Part I, in which the topic of divine teleology is taken up at length, Spinoza writes:

[T]his doctrine concerning the end turns nature completely upside down. For what is really a cause, it considers as an effect, and conversely [NS: what is an effect it considers as a cause]. What is by nature prior, it makes posterior. And finally, what is supreme and most perfect, it makes imperfect.

Although some contemporary philosophers have seen in this passage the indication of a general critique of teleology, its central point is, I think, more focused. Spinoza takes the traditional view of divine teleology to imply that "if the things which have been produced immediately by God had been made so that God would achieve his end, then the last things, for the sake of which the first would have been made, would be the most excellent 
of all." But that suggestion, according to Spinoza, gets the order of perfection the wrong way around. According to Spinoza, God is the most perfect and original source of all being, and among his effects, "the effect is most perfect which is produced immediately by God, and the more something requires intermediate causes to produce it, the more imperfect it is." ${ }^{31}$ As in the case of human teleology, the supposition that God acts for the sake of an objective good thus threatens to confuse explans with explanadum, and in doing so take "away God's perfection. For if God acts for the sake of an end, he necessarily wants something which he lacks.” For Spinoza, it is closer to correct to say that things are perfect insofar as they are produced by God than to say that God acts for the sake of the good things he produces.

Viewed against the backdrop of the heyday of teleology, it is not hard to see why there should be so much disagreement over whether Spinoza was a friend or foe of teleology. For, on the one side, there is good reason to see Spinoza as committed to a position with respect to teleology that is, in important respects, even more permissive than those of his more mainstream contemporaries. Whereas thinkers such as Ockham and Boyle drew a sharp distinction between teleology as applied to rational and nonrational beings, Spinoza's conatus doctrine implies that all finite individuals are teleological in essentially the same in way, differing primarily with respect to degree of sophistication rather than with respect to kind of tendency. Furthermore, whereas more conservative thinkers of the early modern period conspicuously abandoned the view that final and efficient causal explanations should be on a par, Spinoza's conatus doctrine

${ }^{31} \mathrm{Cf}$. Aquinas, SCG IIIa, 64: "Whoever has an end in view, cares more for what is nearest to the last end: because the other ends are directed to this." 
suggests that the actions of every singular mode - whether viewed through the attribute of mind or body - should be explicable equally well in terms of antecedent (efficient) causes and in terms of the end of self-preservation (Ethics III, p2s). On the other side, however, in not only denying that teleological explanations may be extended to God, or nature as a whole, but also, and even more centrally, in rejecting the view that things act for the sake of the good, Spinoza set himself against the views of his more mainstream contemporaries and consciously breaks with a long tradition reaching back through the middle ages to the ancient Greeks.

\section{Paradise Regained?: Leibniz's Defense of Traditional Teleology}

In a well-known piece from the late 1670's that has been entitled Two Sects of Naturalists, Leibniz explicitly divides his contemporaries into two groups of philosophers distinguished by their attitudes towards materialism but united in their rejection of final causes. $^{32}$ In opposing both groups, he counsels a return to "the sect of Socrates and Plato" as being "so much more suitable for piety," and quotes approvingly, and at length, the famous passage from the Phaedo in which, as Leibniz describes it, Socrates "maintains that final causes are the principles in physics and that we must seek them in order to account for things." But what exactly is at stake in Leibniz's proposed defense of traditional teleology? What developments among his contemporaries does he wish to combat? And what does he mean to place in their stead? The next two subsections will

\footnotetext{
${ }^{32}$ A.6.iv.1384-1388/AG 281-284; see also A.2.i.499-504/AG240-245; cf. Boyle, “A Disquisition About the Final Causes of Natural Things," section 1.
} 
suggest that Leibniz's attempt to revive what he sees as traditional teleology is - in its broadest terms - an effort to restore the theses of explanatory goodness and parity that had largely been abandoned, in one way or another, by his contemporaries. In doing so he is led to posit a series of remarkable explanatory parallelisms that affirm the legitimacy of teleological explanations in terms of the good while at the same time acknowledging the - at least in principle - equipotency of final and efficient causal explanations.

\subsection{Defending Explanatory Goodness}

There can be little doubt that Leibniz means to uphold the once standard view that rational agents act for the sake of ends they perceive as being good. Indeed, he suggests that the will "taken in a general sense" simply "consists in the inclination to do something in proportion to the good it contains" (T22). Applying this general formula to the divine will, Leibniz is led to distinguish between God's antecedent will, as an inclination to every particular good, and God's "consequent" will, the vector sum as it were, pointing towards the best possible (aggregated) outcome:

This will is called antecedent when it is detached, and considers each good separately in the capacity of a good. In this sense it may be said that God tends to all good, as good, ... Now this consequent will, final and decisive, results from the conflict of all the antecedent wills, of those which tend towards good ... and from the concurrence of all these particular wills comes the total will. Thence it follows that God wills antecedently the good and consequently the best. (T 22-23) 
Essentially the same picture, Leibniz suggests, may be applied to finite wills as well. Rebuffing "modern philosophers who go so far as to say that God is the only agent," Leibniz maintains that the human will "tends towards good in general, [that] it must strive after the perfection that befits us," declaring further that "I am of the opinion that the [human] will is always more inclined towards the course it adopts ... [so that] when one speaks of the greater inclination of the will, one speaks of the result of all the inclinations. It is almost as we have spoken ... of the consequent will in God, which results from all the antecedent wills" (T 32, 43).

In maintaining that both God and rational creatures will, antecedently, whatever they perceive to be good, and, consequently, whatever they perceive to be best, Leibniz exposes himself to the very charges that had helped to drive so many of his contemporaries and predecessors away from the thesis of explanatory goodness, and his attempts to address those concerns represent some of the most central commitments of his philosophical program. In responding to the charge that his account of divine choice entails necessitarianism, Leibniz famously distinguishes between what is absolutely necessary and what is only morally necessary. He argues that God's choice of the best of all possible worlds is not absolutely necessary since there remain other possible worlds that God does not, and will not, create because they are incompossible with his creation of the best of all possible worlds. Following essentially the same line of thought, Leibniz argues similarly that the actions of finite creatures are not absolutely determined since they do not follow "of logical or metaphysical necessity" (T 53). Less famously, but even more tellingly for our present purposes, Leibniz also insists that to be determined by considerations of the good is, at any rate, fully consistent with full-blooded freedom. 
Thus after suggesting, in keeping with "the opinion of all the ancients, of Plato, of Aristotle, of St. Augustine," that the "will is never prompted to action save by the representation of the good," he goes on to emphasize that to be determined by the best is "not a defect where God and the saints are concern: on the contrary, it would be a great defect, or rather a manifest absurdity, were it otherwise, even in men here on earth ... if they were capable of acting without any inclining reason" ( $\mathrm{T} 45)$.

Leibniz's understanding of the divine will, when paired with his commitment to the doctrine of divine creation, entails a further commitment to things existing and being ordered within the world because they are good. He thus affirms, for example, that because "the author of the world understands all things, he makes all things act with order, which is to say towards an end," adding that not only is the world ordered to such "general final causes," but that there also arise in the world "particular final causes," especially "in machines of nature, or in the organic bodies of living beings, which are machines of divine invention, suited for a certain variety of operations" (Animadversiones 3; see also G 273/L 479). Indeed, Leibniz goes a step further effectively siding with Boyle against Descartes - in insisting that consideration of ends may be positively useful for making discoveries in the natural sciences. While conceding that we cannot hope to know all of God's ends, nor ends that God wishes to conceal from us, Leibniz nonetheless maintains that there is no reason to suppose that we might not have some understanding of the ends that God has seen fit to reveal. Thus noting that the "ancients already discerned something when they said that nature does nothing in vain, but tends towards an end, and other things of this sort that the moderns wrongly disapproved," Leibniz suggests, as an example, that "looking at the use of the parts and 
the ends of nature" is obviously useful in the study of "animal economy and in medical practice" since even though "effects arise from the internal motions and structure of the machine, nevertheless, since their interiors are unknown, they are easier to conjecture from ends than from mechanism" (Animadversiones 3).

\subsection{Defending Explanatory Parity}

In embracing and defending the view that the actions of God and finite rational creatures may be determined by the good, Leibniz simply rejects the principal motivation among his contemporaries for abandoning the thesis of explanatory parity, and with his repeated invocations of the Pheado passage he signals his conviction that final causes should be viewed as being at least as explanatory as efficient causes (see, for example, DM 20/AG 53). Beyond this general proposal to uphold the thesis of explanatory parity by rejecting the concerns that had led to its demise, however, Leibniz also develops the idea of explanatory equality via his defense of three distinguishable explanatory parallelisms within the created world.

The first of those parallelisms is rooted in Leibniz's famous doctrine of preestablished harmony - that is, the doctrine that the apparent interaction between a soul and its body is the result of two autonomous, but divinely synchronized, unfoldings, one of the mind, one of the body. That Leibniz sees this doctrine as not only offering a solution to the problem of mind-body interaction in general, but also as specifically grounding a parallelism between final and efficient causation is brought out nicely in a text recently edited and translated by Justin Smith: 
The parallelism between the body and the soul contains the system of preestablished harmony, of which I am the discoverer. ... [W]hen the soul desires some outcome, its machine is spontaneously inclined and prepared, by its innate motions, towards accomplishing it; and vice versa, when the soul perceives the mutations of the body, it is not from the body disturbing the laws of the soul ... And in this way it comes about that the natural reason of all things can be found in the soul and in the body, as the present state of the body arises from the preceding state according to the laws of efficient causes, and the present state of the soul arises from the preceding state according to the laws of final causes. In the former case the series of motions, in the latter the series of appetites, takes place: in the former it is a matter of transition from the cause to the effect; in the latter, from the end to the means. (Animadversiones 3$)^{33}$

The central point of Leibniz's suggestion here is clear enough. His doctrine of preestablished harmony implies that the activities of every ensouled creature may be explained equally well in either of two ways. The actions of such a creature might be explained teleologically by citing its perceptions and appetitions, or efficiently by citing the mechanistic causes involved in the motions of its body. The harmony that Leibniz has in view here, however, gets further bite from two additional commitments of his metaphysics. The first is that, according to Leibniz, "every finite soul is embodied, even

\footnotetext{
${ }^{33}$ Similarly: "Souls act according to the laws of final causes, through appetitions, ends, and means. Bodies act according to the laws of efficient causes or of motions. And these two kingdoms, that of efficient causes and that of final causes, are in harmony with each other" (Mon 79/AG 223).
} 
the angels are not excepted" so that for every created soul there is a corresponding body, and so for every teleological explanation of a creature's activity, there will also be a mechanistic account as well (A VI.iii.158-9; see also A VI.ii 74, A.VI.ii.518/DSR 76, GM III 560/AG 170, G IV 480/AG 140-1). The second is that, according to Leibniz, at one level of analysis, the world itself is exhaustively constituted by organic unions of souls and bodies so that even in apparently "unformed masses there are certainly machines of nature concealed ... like the multitude of fish swimming in the water" of a pool (Animadversiones 3). Together these two commitments suggest that from the right perspective everything that happens in the created world may be seen as arising from the activity of creatures that are both goal-directed and efficiently driven. It is with this symmetry in mind, that Leibniz asserts that there is "a twofold and most perfect parallelism ... between the material and formal principles, or between the body and soul" (Animadversiones 3).

Leibniz's relatively well-known parallelism between the mind and body has overshadowed two less widely recognized final/efficient explanatory parallelisms within his system. Leibniz's second final/efficient parallelism holds within the domain of mental activity itself. As we have just seen, Leibniz maintains that every mind unfolds according to its own teleological law - is "pulled" along as it were by its perceptions and desires of ends and means. Each created mind, or monad, for Leibniz, however, may also be seen as being driven along by its past perceptions and appetitions according to its own quasi-mechanstic "law of the series," and Leibniz relates explicitly that "the representation of the end in the soul is the efficient cause of the representation in the 
same soul of the means" (Dutens 2.2.134). ${ }^{34}$ For Leibniz therefore, each state of a monad can be seen as the result either of a teleological process governed ultimately by the creature's perception of the good, or by an efficient causal process involving prior conditions and the monad's own distinctive causal ordering. In affirming that the actions of any organic unity can be explained either in terms of the final causes of its soul, or in terms of the efficient causes of its body, Leibniz thus does not mean to deny that a creature's mental life does not have its own, immediate efficient causes. This might, of course, be surprising if we were to assume that teleological and efficient explanations

${ }^{34}$ For discussion of Leibniz's views concerning the efficient causality of monads, especially in relation to their also being loci of final causality, see: Marc Bobro and Kenneth Clatterbaugh, "Unpacking the Monad: Leibniz's Theory of Causality," Monist 79 (1996). Laurence Carlin, “Leibniz on Final Causes," Journal of the History of Philosophy 44 (2006). John Carriero, "Substance and Ends in Leibniz," in Contemporary Perspectives on Early Modern Philosophy: Essays in Honor of Vere Chappell, ed. Paul Hoffman, David Owen, and Gideon Yaffe (Peterborough, ON: Broadview Press, 2008). Sukjae Lee, “Leibniz on Divine Concurrence," Philosophical Review 113, no. 2 (2004). Jeffrey K. McDonough, “Leibniz: Creation and Conservation and Concurrence,” The Leibniz Review 17 (2007). Jeffrey K. McDonough, "Leibniz on Monadic Agency and Optimal Form ” (2011). Marleen Rozemond, "Leibniz on Final Causation,” in Metaphysics and the Good: Themes from the Philosophy of Robert Merrihew Adams, ed. Samuel Newlands and Larry M. Jorgensen (New York: Oxford University Press, 2009). Donald Rutherford, "Leibniz on Spontaneity," in Leibniz: Nature and Freedom, ed. Donald Rutherford and J. A. Cover (New York: Oxford University Press, 2005). 
must always be rival accounts of phenomena - that any given phenomenon must be explicable either in terms of final or efficient causes. But Leibniz, like the most of his predecessors, shows no sign of accepting any such dichotomy; he is thus free to maintain that the unfolding of any particular monad may be explained both in terms of final and efficient causes.

Leibniz's third final/efficient explanatory parallelism is applicable to the world even when viewed - as in physics - as an idealized system of gross bodies acting upon one another in accordance with the laws of nature. Although often cited as a critic of broadly mechanist philosophers from Descartes to Newton, Leibniz too was a champion of the New Science and accepted the dogma of his day that the actions of gross bodies can always, at least in principle, be fully explained by appeal to quantitative properties and efficient causal laws. Nonetheless, from quite early in his career, Leibniz defended an alternative style of lawful explanation, which he took to be a vindication of teleological reasoning even as applied to natural phenomena. ${ }^{35}$ Leibniz's favorite example of such an explanation is drawn from his work in geometrical optics, and is closely related to Fermat's proposal that a ray of light must always take the quickest path between its source (e.g. a candle) and its sink (e.g. an eye). While Leibniz agrees with

\footnotetext{
${ }^{35}$ For discussion of this theme in Leibniz's philosophy, see: David Hirschmann, "The Kingdom of Wisdom and the Kingdom of Power in Leibniz," Proceedings of the Aristotelian Society 88 (1988), Jeffrey K. McDonough, “Leibniz's Two Realms Revisited," Noûs 42, no. 4 (2008). Jeffrey K. McDonough, "Leibniz on Natural Teleology and the Laws of Optics," Philosophy and Phenomenological Research 78, no. 3 (2009).
} 
Descartes, Huygens, Newton and others that the behavior of light may in principle be explained in broadly mechanistic, efficient causal terms, he also sees in Fermat's approach the possibility of providing teleological explanations of the behavior of light. If, for example, we suppose that light must always travel from its source to its sink by the quickest path available, then we may explain its going through some particular point by appealing to the result of its going through that point - that is, we may say that it passes through some point in order to take the quickest possible path. Consequently, we may explain the behavior of a ray of light in a way that is structurally similar to the way in which we might explain someone's taking the Red Line from Kendall Square to MGH by appealing to her goal of traveling from one T-stop to another by the quickest route available. Leibniz's successful efforts to extend this model of explanation to other phenomena, including bending beams, hanging chains, and descending bodies, together with his unwavering conviction that all natural phenomena can also be explained in terms of efficient mechanical laws lie behind his bold assertion that there are "two kingdoms even in corporeal nature, which interpenetrate without confusing or interfering with each other - the realm of power, according to which everything can be explained mechanically by efficient causes when we have sufficiently penetrated into its interior, and the realm of wisdom, according to which everything can be explained architectonically, so to speak, or by final causes when we understand its ways sufficiently" (TA 479/G 273).

Although we have only scratched the surface of Leibniz's complex and multifaceted defense of teleology, it should be clear enough already that Leibniz's world is not only a world in which goodness is explanatory, but also one in which teleological explanations are genuine rivals to efficient causal explanations. For Leibniz, the whole 
of creation can be viewed alternatively as being constituted by divinely harmonized minds, organisms, or gross bodies. In whatever way it is approached, however, he maintains that there are parallelisms to be found between its unfolding according to the laws of efficient and final causation. As a universe of monads, everything that happens in the world can be seen to be the result of the unfolding of countless mental lives that can, in principle, be seen as being "driven" from behind by efficient causes or "pulled" ahead by final causes. As a universe of organisms, everything that happens in the world can be seen to result from the desires and intentions of creatures, or as following from the mechanistic consequences of their bodily movements. As a world of gross bodies, everything that happens in the world can be seen to follow either from initial conditions and efficient laws of nature or from outcome constraints and teleological laws of nature. Although Leibniz's world is undeniably in many respects novel and radical, it is nonetheless also, in an important sense, a return to an old older worldview - to a worldview in which teleology is both bound up with the good, and placed on a par, or better, with efficient causal explanations.

\section{Conclusion}

As noted at the outset, Don Garrett, in his essay "Teleology in Spinoza and Early Modern Rationalism," has suggested that the common portrayal of the friends and foes of traditional teleology "while not entirely baseless is largely misleading." 36 Since his

${ }^{36}$ Garrett, "Teleology in Spinoza and Early Modern Rationalism," 311. 
conclusion is rooted in how he believes Aristotle, Descartes, Spinoza and Leibniz would answer a series of questions, one especially straightforward way of responding to Garrett's account would be to contest the specific answers he offers on behalf of the philosophers he considers. One might thus argue, for example, that Descartes and Leibniz do, in important senses, allow for teleology that is not dependent upon thought; that the absence of divine teleology in the philosophies of Aristotle and Spinoza reflects not so much their shared views concerning teleology as it does their shared rejection of the existence of a transcendent creator; that Leibniz's views on subhuman and natural teleology are closer to Aristotle's than are Spinoza's in virtue of his explicit reintroduction of entelechies alone. But while such a point-by-point response might indeed go a considerable way towards responding to Garrett's reevaluation, it would nonetheless tacitly cconede what is I think an even deeper assumption, namely, that early modern allegiances to and divergences from traditional teleology should be measured by the points of comparison that Garrett raises - that whether a philosopher upheld or attacked traditional teleology is best determined by whether he agrees with Aristotle concerning thoughtful, divine, subhuman and natural teleology.

The present essay has therefore pursued a different tack. Seeking to identify what was distinctive and central to traditional teleology, the first section highlighted the theses of explanatory parity and goodness as two hallmarks of ancient and early medieval views on teleology. The second section then argued that mainstream philosophers of the later medieval and early modern eras came to oppose - on both conceptual and theological grounds - the thesis of explanatory parity, arguing that intelligent agents act first and foremost as efficient causes, and that non-rational creatures enjoy ends only derivatively 
in virtue of being designed and used by intelligent agents. The third section argued that Spinoza, drawing rather different lessons from the philosophical and theological developments of his time, denied the thesis of explanatory goodness, insisting that neither God nor creatures act for the sake of the good even while allowing that singular things might nonetheless strive to preserve their own existence. Finally, in the last section, it was argued that Leibniz's claim to being a champion of a traditional teleology is justified by his efforts to defend, against the currents of his time, both the thesis of explanatory parity and the thesis of explanatory goodness.

It is, of course, not the intent of the present essay to suggest that the theses of explanatory parity and goodness exhaust what is distinctive about traditional teleology, or to imply that no other standards of evaluating the relationship between traditional teleology and early modern philosophy might be both useful and appropriate. Nonetheless, it might more modestly suggest three general lessons, or "cautions," concerning the assessment of early modern teleology in comparison with the views of earlier thinkers. First, although it is tempting to categorize the views of early modern philosophers on the basis of the range of teleological explanations they endorsed, such an approach is potentially quite misleading. For, as we have seen, philosophers of the period differed from one another not only with respect to the domains in which they thought teleological explanations might be applied, but also, and often more significantly, with respect to what they took teleology and teleological explanations to involve. Second, attention to the undeniable pressure of the New Science on early modern attitudes towards teleology and teleological explanations should not be allowed to obscure the powerful influence of broadly theological concerns on the causal and 
explanatory mores of the era. For, again, as we have seen, while the development of mechanistic physics may have encouraged the rethinking of the relationship between final and efficient causation, such worries were generally taken up within the context of an even larger and more dominant framework of moral and religious concerns. Finally, in considering the relationship between early modern views on teleology and views of the still more distant past, it is important to bear in mind that ancient and medieval views on teleology were not exhausted by the views of Aristotle and his followers. In viewing the world as a rationally designed system ordered in light of the good, many later medieval and early modern philosophers could see themselves as intellectual descendants of Plato even as they sought to distance themselves from the legacy of his most famous pupil. ${ }^{37}$

\footnotetext{
${ }^{37}$ Earlier versions of this paper were presented to audiences at The Scottish Seminar in Early Modern Philosophy at the University of Aberdeen, A Spinoza Workshop at the University of Ghent, the Turku Centre for Medieval and Early Modern Studies at the University of Turku, and a Symposium on Teleological Thinking in Scientific Explanations at an Eastern Division Meeting of the American Philosophical Association. I have benefitted greatly from questions and discussion at those meetings. Special thanks are due to John Carriero, James Lennox, Elizabeth Miller, and Laurence Carlin for providing helpful comments on full drafts at various stages. Additional thanks are also due to the Alexander von Humboldt Foundation for its generous financial support during a research leave in which this essay was written. It is an honor for me to have this essay included in a festschrift dedicated to the memory of my friend Paul Hoffman - a wise advisor, esteemed colleague, and dedicated father; he will be greatly missed.
} 


\section{ABBREVIATIONS}

A Gottfried Wilhelm Leibniz. Sämtliche Schriften und Briefe. Ed. Deutsche Akademie der Wissenschaften. Darmstadt, Leipzig, Berlin: Akademie Verlag, 1923-. Cited by series, volume, page.

AG G. W. Leibniz. Philosophical Essays. Ed. and trans. Roger Ariew and Daniel Garber. Indianapolis: Hackett, 1989.

Animadversiones $\quad$ G. W. Leibniz. Animadversiones circa assertiones aliquas

Theoriae Medicae Verae clarii Stahlii. Original language edition reprinted in Ed. L. Dutens. Genevia: Fratres de Tournes, 1768, vol. 2, part 2, pages 131161. Cited by section number. I have followed an unpublished translation by Justin E. H. Smith throughout.

AT Oeuvres de Descartes. Ed. Charles Adam and Paul Tannery. Paris: J. Vrin, 1964-74. Cited by volume and page.

CSM The Philosophical Writings of Descartes. Ed. and trans. John Cottingham, Robert Stoothoff, Dugald Murdoch, and (vol. 3) Anthony Kenny. Cambridge: Cambridge University Press, 1984, 1985, 1991. Cited by volume and page. 
DM G. W. Leibniz. Discours de Métaphysique. Cited by section as in G 4:427-463.

DSR G. W. Leibniz. De Summa Rerum. Metaphysical Papers, 1675-1676. Ed. and trans. G.H.R. Parkinson. New Haven: Yale University Press, 1992.

Ethics Baruch Spinoza. Ethica. Cited by part, axiom, proposition, definition, etc. English translation in The Collected Works of Spinoza. Vol. 1. Ed. and trans. Edwin Curley. Princeton: Princeton University Press, 1985.

Geb Spinoza Opera. Ed. Carl Gebhardt. Heidelberg: Carl Winters, 1925, 1972 [volume 5, 1987]. Cited by volume and page.

GP Die philosophischen Schriften von Gottfried Wilhelm Leibniz. Ed. C. I. Gerhardt. Berlin: Weidmann, 1875-90. Reprint, Hildesheim: Georg Olms, 1978. Cited by volume and page.

GM Leibnizens Mathematische Schriften. Ed. C. I. Gerhardt. Berlin: A. Asher; and Halle: H. W. Schmidt, 1849-63. Reprint, Hildesheim: Georg Olms, 1971. Cited by volume and page.

Principles Rene Descartes. Principia Philosophiae. Cited by part and article, as found in AT, vol. 8, and CSM, vol. 1. 
Meditations $\quad$ Rene Descartes. Meditationes De Prima Philosophia. Cited by part as found in AT, vol. 10, and CSM, vol. 2.

SCG St. Thomas Aquinas. Summa Contra Gentiles. Rome: Editio Leonina Manualis, 1934. English translation in Summa contra gentiles. Trans. A.C. Pegis et al. Notre Dame, IN: University of Notre Dame Press, 1975.

ST St. Thomas Aquinas. Summa Theologiae. Madrid: Biblioteca de Autores Cristianos 1955-1958. Cited by part, question and article. English translation in Summa Theologiae. Trans. the English Dominican Fathers. London: Burns, Oates, and Washburne, 1912-36; New York: Benziger, 194748; Reprint, New York: Christian Classics, 1981.

T G. W. Leibniz. Essais de Theodicée. Cited by section number as in GP 6:21471. English translation in G. W. Leibniz. Theodicy. Trans. E. M. Huggard. New Haven: Yale University Press, 1952. Reprint, La Salle, Ill: Open Court, 1985. 
Bibliography

Adams, Marilyn M. “Duns Scotus on the Will as Rational Power." In Via Scoti:

Methodologica Ad Mentem Joannis Duns Scoti, edited by Leonardo Sileo, 839-

54. Roma, 1995.

———. "Ockham on Final Causality: Muddying the Waters." Franciscan Studies 56 (1998): 1-46.

Aquinas, Thomas. Opera Omnia: Ad Fidem Optimarum Editionum Accurate Recognita. 25 vols. Parma: P. Fiaccadorie, 1852-73.

- - - St. Thomas Aquinas: Selected Writings. Translated by Robert P. Goodwin. Indianapolis, IN: Bobbs-Merrill, 1965.

Aristotle. "Nicomachean Ethics." In The Complete Works of Aristotle, edited by Jonathan Barnes, 1729-867. Princeton, New Jersey: Princeton University Press, 1984.

Augustine. “Confessiones.” In Patrologiae Cursus Completus, Series Latina, edited by J. P. Migne. Paris, 1844-64.

———. "De Civitate Dei." In Patrologiae Cursus Completus, Series Latina, edited by J. P. Migne. Paris, 1844-64.

Bennett, Jonathan. “Spinoza and Teleology: A Reply to Curley.” Paper presented at the Spinoza: Issues and Directions, Leiden 1990.

- - - A Study of Spinoza's Ethics. Indianapolis: Hackett Publishing, 1984.

Bernstein, Howard. "Conatus, Hobbes, and the Young Leibniz." Studies in the History and Philosophy of Science 11, no. 1 (1980): 25-37.

Bobro, Marc, and Kenneth Clatterbaugh. "Unpacking the Monad: Leibniz's Theory of Causality." Monist 79 (1996): 408-25.

Boler, John. "Transcending the Natural: Duns Scotus on the Two Affections of the Will." The American Catholic Philosophical Quarterly 67 (1993): 109-26.

Boyle, Robert. "A Disquisition About the Final Causes of Natural Things." In The Works of the Honourable Robert Boyle, edited by Thomas Birch, 393-444. Hildesheim: Georg Olms, 1966.

Brown, Stephen F. “Ockham and Final Causality.” In Studies in Medieval Philosophy, 249-72. Washington, D. C. : The Catholic University of America Press, 1987.

Carlin, Laurence. "Boyle's Teleological Mechanism and the Myth of Immanent Teleology." Studies in the History and Philosophy of Science (forthcoming).

- - - "The Importance of Teleology to Boyle's Natural Philosophy." British Journal for the History of Philosophy 19, no. 4 (2011): 663-80.

- - _. "Leibniz on Final Causes." Journal of the History of Philosophy 44 (2006): 217-33.

Carriero, John. "Spinoza on Final Causality." Oxford Studies in Early Modern Philosophy 2 (2005): 105-47. 
- - . "Substance and Ends in Leibniz." In Contemporary Perspectives on Early Modern Philosophy: Essays in Honor of Vere Chappell, edited by Paul Hoffman, David Owen and Gideon Yaffe, 115-40. Peterborough, ON: Broadview Press, 2008.

Centore, F. F. "Mechanism, Teleology, and Seventeenth Century English Science." International Philosophical Quarterly 12 (1972): 553-71.

Cohen, I. Bernard. “'Quantum in Se Est': Newton's Concept of Inertia in Relation to Descartes and Lucretius." Notes and Records of the Royal Society of London 19 (1964): 131-55.

Cross, Richard. "Duns Scotus on Goodness, Justice, and What God Can Do." Journal of Theological Studies 48, no. 1 (1997): 48-76.

Curley, Edwin. "On Bennett's Spinoza: The Issue of Teleology." Paper presented at the Spinoza: Issues and Directions, Leiden 1990.

Della Rocca, Michael. Spinoza. New York: Routledge, 2008.

- - - "Spinoza's Metaphysical Psychology." In The Cambridge Companion to Spinoza, edited by Don Garrett, 192-226. New York: Cambridge University Press, 1993.

Dobbs, B. J. T. The Janus Faces of Genius: The Role of Alchemy in Newton's Thought. Cambridge: Cambridge University Press, 1991.

Garrett, Don. "Teleology in Spinoza and Early Modern Rationalism." In New Essays on the Rationalists, edited by Rocco J. Gennaro and Charles Huenemann, 31055. Oxford: Oxford University Press, 1999.

Hirschmann, David. "The Kingdom of Wisdom and the Kingdom of Power in Leibniz." Proceedings of the Aristotelian Society 88 (1988): 147-59.

Hoffman, Paul. "Does Efficient Causation Presuppose Final Causation? Aquinas Vs. Early Modern Mechanism." In Metaphysics and the Good, edited by Samuel Newlands and Larry M. Jorgensen, 295-312. New York: Oxford University Press, 2009.

Kaufman, Dan. "Infimus Gradus Libertatis? Descaretes on Indifference and Divine Freedom." Religious Studies 39 (2003): 391-406.

Kremer, Klaus. “Das 'Warum' Der Schoepfung: 'Quia Bonus' Vel/Et 'Quia Voluit'? Ein Beitrag Zum Verhaeltnis Von Neuplatonismus Und Christentum an Hand Des Prinzips 'Bonum Est Diffusivum Sui'." In Parusia: Studien Zur Philosophie Platons Und Zur Problemgeschichte Des Platonismus, Festgabe Fuer Johannes Hirschberger, edited by Kurt Flasch, 241-54. Frankfurt am Main: Minerva, 1965.

Kretzmann, Norman. "A General Problem of Creation: Why Would God Create Anything at All?" In Being and Goodness: The Concept of the Good in Metaphysics and Philosophical Theology, edited by Scott MacDonald, 208-28. Ithaca, NY: Cornell University Press, 1991.

Lee, Sukjae. "Leibniz on Divine Concurrence." Philosophical Review 113, no. 2 (2004): 203-48.

Leibold, Gerhard. "Zum Problem Der Finalität Bei Wilhem Von Ockham." Philosophisches Jahrbuch 89 (1982): 347-83.

Lennox, James G. "Plato's Unnatural Teleology." In Platonic Investigations, edited by Dominic J. O'Meara. Washington, D.C.: Catholic University of America, 1985. 
- - . "Robert Boyle's Defense of Teleological Inference in Experimental Science." Isis 74 (1983): 38-52.

Lin, Martin. "Teleology and Human Action in Spinoza." Philosophical Review 115, no. 3 (2006): 317-54.

MacDonald, Scott, ed. Being and Goodness: The Concept of the Good in Metaphysics and Philosophical Theology. Ithaca, NY: Cornell University Press, 1991.

Maier, Anneliese. "Das Problem Der Finalkausalität Um 1320." In Metaphysische Hintergründe Der Spätscholastischen Naturphilosophie, 273-99. Rome: Edizioni di storia e letteratura, 1955.

Manning, Richard. "Spinoza, Thoughtful Teleology, and the Causal Significance of Content." In Spinoza: Metaphysical Themes, edited by Olli Koistinen and John Biro, 182-209. New York: Oxford University Press, 2002.

McDonough, Jeffrey K. "Leibniz on Monadic Agency and Optimal Form ", 2011.

- - - "Leibniz on Natural Teleology and the Laws of Optics." Philosophy and Phenomenological Research 78, no. 3 (2009): 505-44.

- - . "Leibniz: Creation and Conservation and Concurrence." The Leibniz Review 17 (2007): 31-60.

———. "Leibniz's Two Realms Revisited." Noûs 42, no. 4 (2008): 673-96.

Ockham, William of. "Opera Philosophica Et Theologica." edited by Gedeon Gál. St. Bonaventure, NY: The Franciscan Institute, 1967-88.

Osler, Margaret J. "From Immanent Natures to Nature as Artifice: The Reinterpretation of Final Causes in Seventeenth-Century Natural Philosophy." The Monist 79, no. 3 (1996): 388-407.

Peghaire, Julien. "L'axiome 'Bonum Est Diffusivum Sui' Dans Le Néoplatonisme Et Le Thomisme." Revue de l'Université d'Ottawa 1 (1932): 5*-30*.

Plato. "Plato Complete Works." edited by John M. Cooper and D.S Hutchinson. Indianapolis, IN: Hackett, 1997.

Rozemond, Marleen. "Leibniz on Final Causation." In Metaphysics and the Good: Themes from the Philosophy of Robert Merrihew Adams, edited by Samuel Newlands and Larry M. Jorgensen, 272-94. New York: Oxford University Press, 2009.

Rutherford, Donald. "Leibniz on Spontaneity." In Leibniz: Nature and Freedom, edited by Donald Rutherford and J. A. Cover, 156-80. New York: Oxford University Press, 2005.

Sarasohn, Lisa T. Gassendi's Ethics: Freedom in a Mechanistic Universe. Ithaca, NY: Cornell University Press, 1996.

Schmaltz, Tad. Descartes on Causation. New York: Oxford University Press, 2008.

Scotus, John Duns. "Works.” edited by Luke Waddington. Hildesheim: Georg Olms, 1639.

Shanahan, Timothy. "Teleological Reasoning in Boyle's Disquisition About Final Causes." In Robert Boyle Reconsidered, edited by Michael Hunter, 177-92. Cambridge: Cambridge University Press, 1994.

Sleigh, Robert JR., Vere Chappell, and Michael Della Rocca. "Determinism and Human Freedom." In The Cambridge History of Seventeenth-Century Philosophy, edited by Daniel Garber and Michael Ayers, 1195-216. Cambridge: Cambridge University Press, 2003. 
Smaltz, Tad. "Descartes's Critique of Scholastic Teleology." 2011.

Stump, Eleonore, and Norman Kretzmann. "Being and Goodness." In Being and Goodness: The Concept of the Good in Metaphysics and Philosophical Theology, edited by Scott MacDonald, 98-128. Ithaca, NY: Cornell University Press, 1991.

Suárez, Francisco. Disputationes Metaphysicae. 2 vols. Hildesheim: G. Olms, 1965.

Teske, Roland J. "The Motive for Creation According to Saint Augustine." The Modern Schoolman 65 (1988): 245-53.

Thijssen, Hans. "Condemnation of 1277." In The Stanford Encyclopedia of Philosophy, edited by Edward N. Zalta, Fall 2008.

Westfall, Richard S. Science and Religion in Seventeenth-Century Englad. Ann Arbor, MI: University of Michigan Press, 1973.

Williams, Thomas. "The Unmitigated Scotus." Archiv für die Geschichte der Philosophie 80 (1998): 162-81.

Wojcik, Jan W. Robert Boyle and the Limits of Reason. Cambridge: Cambridge University Press, 2002.

Wolter, Allan B. "Duns Scotus on the Will as a Rational Potency." In The Philosophical Theology of John Duns Scotus, edited by Marilyn M. Adams, 163-80. Ithaca: Cornell University Press, 1990.

- - , ed. Duns Scotus on the Will and Morality. Washington, D. C.: The Catholic University of America Press, 1986. 